\title{
nature
}

\section{Hope for best, prepare for worst}

Enigmatic North Korea has government officials around the world anxious. Scientists in East Asia should be thinking about how they might be involved.

$\mathrm{T}$ he people of East Asia are nervous. North Korean President Kim Jong-Il probably has, or will have, nuclear weapons. A recent poll carried out by a popular Japanese news programme found him the "scariest world leader" (52\%), followed by United States President George Bush (34\%). With negotiations between these two countries decidedly rocky, the future security of East Asian countries cannot be taken for granted.

Moreover, there is tension between the United States on one hand and South Korea and Japan on the other over dealing with North Korea. This is forcing the East Asian countries, although still largely dependent on the United States for their defence, to take a second look at their own militaries. As part of this assessment, governments in these countries, along with others such as Taiwan, will be reconsidering their nuclear posture.

Scientists must be involved with these debates, both domestically and regionally. In the past, much of the tough thinking concerning the military application of science was the preserve of scientists in the United States, the Soviet Union, and other key players in the cold-war arena. Since the Manhattan Project, American scientists have sought, rightly, to play a central role in helping to shape decisions about how their knowledge should be used.

This effort has not always been successful, but it has been the least that could be expected ethically from the people whose technical expertise made nuclear weapons possible. (Many of those scientists who did not adequately consider the larger picture early in the development of nuclear weapons admitted regret in the following years.)
The consciousness concerning such issues in East Asia appears to be minimal (see pages 110-111). Scientists are adopting the attitude that war is something for the government to deal with. This attitude reflects their ideal for their lives in research: don't let political considerations skew your objectivity; focus on your research.

A researcher's career, so this argument runs, is defined by following pure curiosity, not by getting hitched to some political agenda. In Japan especially, researchers try to follow this ideal — so much so that would-be entrepreneurs have trouble getting university professors involved in start-up companies.

No one wishes to encourage researchers who, for example, take advantage of tensions in diplomacy to seek increased funds for their research project. But researchers in the West and even India and Pakistan seem to be more outspoken in promoting the military role of scientists. In East Asia, in contrast, they seem to be happy to stay in the background, to focus on their research.

But just because they do not seek active involvement does not mean that they and their research will not be enlisted. Military preparations require science-based research and development, from the analysis of an enemy's capabilities to the design and production of weapons.

If researchers are willing to leave decisions considering the military application of science to politicians, they will all too possibly become involved in ways that they could never have anticipated. Like it or not, scientific research - especially that in military-related fields - plays a political role. If leading researchers are not actively engaged in defining this role, those much less qualified will do so.

\section{Berlin's university crisis}

German universities must take drastic decisions, to pursue a more flexible approach to education and research.

t is a sad twist of fate that Berlin's venerable Humboldt University is associated with the most alarming shock to Germany's academic system since the war. Responding to announced cuts of up to 600 million (US $\$ 680$ million) in its 2006-09 budget, the university has said that it will not admit students for next winter term as it cannot guarantee proper scientific training and reasonably quick completion of studies.

Alexander von Humboldt, the nineteenth-century Berlin-born naturalist and geographer, was the founder of the modern German higher-education system. Its so far unshakeable principle, the unity of teaching and research, made Germany a cradle of modern science in the first half of the twentieth century. The success of science in Europe, the United States and Japan can be traced back to Humboldt's university ideals.

It is not difficult to see why, while Harvard and Oxford flourish, the Berlin original is on crutches. Berlin is still struggling with the immense costs of German reunification. Not only its three universities but also its opera houses, theatres, kindergartens and welfare facilities are facing major budget crises.

But the Humboldt University's unprecedented move - an act of despair committed on shaky legal ground - illustrates a fundamental problem of the higher-education system throughout Germany. Only a small minority of the 200,000 students who enrol each year at its 100 or so research universities is seeking a full scientific education. The majority would be satisfied with a solid academic training that qualifies them for a decent job outside research. But German universities aim at making researchers of them all. And they offer this for free: tuition fees are unknown in Germany.

This has much to do with deeply rooted anti-elitism, based on the respectable belief that everybody should have the same educational opportunities. Only in the past few years has hyper-egalitarianism rightly begun to be questioned. The recent introduction of bachelor degrees and fees for long-term students is surely only the start of change. The allocation of scarce resources must be rethought, and not only in Berlin, in order to keep the system competitive and viable.

The current merger of Berlin's medical faculties is a step in the right direction. Germany-wide, excellence in research needs selectivity without sacrificing training opportunities for as many as possible. Not every university need be a research hot-spot, and not every student needs to be trained by world-class scientists. If further down the road the Humboldt University becomes a centre of excellence in a more diversified university landscape, so much the better. 